\title{
The Pore Size Distribution of Naturally Porous Cigarette Paper and its Relation to Permeability and Diffusion Capacity *
}

\author{
by \\ Bernhard Eitzinger ${ }^{1}$, Maria Gleinser ${ }^{2}$, Stefan Bachmann ${ }^{2}$, and Dietmar Volgger ${ }^{2}$ \\ 1 delfortgroup AG, Fabrikstr. 20, 4050 Traun, Austria \\ 2 Papierfabrik Wattens GmbH \& Co KG, Ludwig-Lassl-Str. 15, 6112 Wattens, Austria
}

\section{SUMMARY}

The pore size distribution of cigarette paper determines its air permeability and diffusion capacity and thereby has a significant influence on the gas exchange of a cigarette through the cigarette paper during smoking and during smouldering. For the design of cigarettes and in particular of cigarette papers it is important to understand how the pore size distribution of the cigarette paper is affected by the paper composition and paper properties and how it influences air permeability and diffusion capacity.

It was the aim of this study to investigate how the composition of the cigarette paper such as filler content, fibre type and burn additive content qualitatively influenced the pore size distribution and how the pore size distribution and, in particular, which pore size range is correlated with air permeability and diffusion capacity, respectively. To this end eight naturally porous cigarette papers were selected which differed in air permeability, diffusion capacity, fibre type, filler content and burn additive content. The pore size distributions of these papers were measured by mercury porosimetry before and after the papers had been heated to $230{ }^{\circ} \mathrm{C}$ for $30 \mathrm{~min}$. The pore size distributions were investigated for qualitative differences when air permeability, fibre type and filler content of the cigarette paper are modified. Furthermore by appropriate weighting of the pore size distributions optimal correlations between a weighted pore volume and air permeability or diffusion capacity were determined. The results show a good correlation with correlation coefficients greater than 0.9 for air permeability as well as for diffusion capacity. The results indicate that large pores are better correlated with changes in air permeability, while small pores are more strongly correlated with changes in diffusion capacity and support previous theoretical results obtained from flow and diffusion models. They also demonstrate the tight relationship between pore size distribution, air permeability and diffusion capacity, which makes the pore size distribution a tool to further optimize cigarette papers, for example, with respect to carbon monoxide yields in the smoke of a cigarette. [Beitr. Tabakforsch. Int 26 (2015) 312-319]

\section{ZUSAMMENFASSUNG}

Die Luftdurchlässigkeit und die Diffusionskapazität eines Zigarettenpapiers werden durch dessen Porengrößenverteilung bestimmt und sie hat daher sowohl während des Rauchens als auch während des Glimmens einen bedeutenden Einfluss auf den Gasaustausch auf der Zigarette durch das Zigarettenpapier hindurch. Für die Gestaltung von Zigaretten und insbesondere von Zigarettenpapieren ist es wichtig zu verstehen, wie die Porengrößenverteilung des Zigarettenpapiers durch die Papierzusammensetzung und die Papiereigenschaften beeinflusst wird und wie sie von sich aus wiederum die Luftdurchlässigkeit und die Diffusionskapazität beeinflusst.

Das Ziel dieser Studie war es zu untersuchen, wie die 
Zusammensetzung des Zigarettenpapiers, beispielsweise der Füllstoffgehalt, die Art der Fasern und der Brandsalzgehalt die Porengrößenverteilung qualitativ beeinflusst und wie die Porengrößenverteilung, insbesondere welcher Bereich der Porengrößen, mit Luftdurchlässigkeit bzw. Diffusionskapazität korreliert ist. Dazu wurden acht natürlich poröse Zigarettenpapiere ausgewählt, die sich in Luftdurchlässigkeit, Diffusionskapazität, Faserart, Füllstoffgehalt und Brandsalzgehalt unterschieden. Die Porengrößenverteilungen dieser Papiere wurde mittels Quecksilberporosimetrie gemessen bevor und nachdem die Papiere für 30 Minuten auf $230^{\circ} \mathrm{C}$ aufgeheizt wurden. Die Porengrößenverteilungen wurden hinsichtlich ihrer qualitativen Unterschiede untersucht, wenn die Luftdurchlässigkeit, der Fasertyp und der Füllstoffgehalt verändert wurden. Des Weiteren wurden durch geeignete Gewichtung der Porengrößenverteilung optimale Korrelationen zwischen dem gewichteten Porenvolumen und der Luftdurchlässigkeit bzw. Diffusionskapazität bestimmt. Die Ergebnisse zeigen eine gute Korrelation mit Korrelationskoeffizienten von über 0,9 für die Luftdurchlässigkeit und die Diffusionskapazität. Die Ergebnisse zeigen auch, dass große Poren besser mit Veränderungen der Luftdurchlässigkeit und kleinere Poren besser mit Veränderungen der Diffusionskapazität korreliert sind. Sie stützen damit frühere theoretische Vorhersagen aus Strömungs- und Diffusionsmodellen. Sie zeigen auch, dass ein enger Zusammenhang zwischen Porengrößenverteilung, Luftdurchlässigkeit und Diffusionskapazität besteht, was die Porengrößenverteilung zu einem Hilfsmittel macht, um das Zigarettenpapier weiter $\mathrm{zu}$ optimieren, beispielsweise hinsichtlich des Gehalts an Kohlenmonoxid im Rauch einer Zigarette. [Beitr. Tabakforsch. Int 26 (2015) 312-319]

\section{RESUME}

La distribution de la taille des pores détermine la perméabilité d'air et la capacité de diffusion d'un papier à cigarettes, et par conséquent elle a une influence signifiante sur les échanges gazeux à travers le papier à cigarettes, non seulement d'une cigarette allumée, mais aussi d'une cigarette qui s'éteint. Pour le dessin des cigarettes, et notamment des papiers à cigarettes, il faut comprendre comment la distribution de la taille des pores du papier à cigarettes est influencée par la structure et les qualités du papier, ainsi que comment la distribution de la taille des pores influence la perméabilité d'air et la capacité de diffusion.

Cette étude a pour objectif d'examiner l'influence de la composition du papier à cigarettes - comme par exemple les charges ajoutées, les fibres et les additifs de combustionsur la qualité de la distribution de la taille des pores, et comment la distribution et avant tout quelle taille des pores est en corrélation avec la perméabilité d'air ou encore la capacité de diffusion. Pour cela on a choisi huit papiers à cigarettes naturellement poreux qui diffèrent par perméabilité d'air, capacité de diffusion, sortes de fibres, charges et additifs de combustion. Les distributions de la taille des pores de ces papiers one été mesurées à l'aide de la porosimétrie mercure avant et après avoir chauffé les papiers à $230{ }^{\circ} \mathrm{C}$ pendant $30 \mathrm{~min}$.

On a examiné les différences de qualité des distributions de la taille des pores si l'on change la perméabilité d'air, la sorte des fibres, et les charges ajoutées. En plus, on a déterminé - à l'aide de l'importance propre à la distribution de la taille des pores - une corrélation optimale entre le volume important des pores, la perméabilité d'air et la capacité de diffusion.

Les résultats démontrent une bonne corrélation avec un coefficient de corrélation de plus de 0.9 pour la perméabilité d'air et la capacité de diffusion. En plus, les résultats prouvent que les pores de grande taille s'accordent mieux avec les changements de la perméabilité, les pores de petite taille par contre avec les changements de la capacité de diffusion. Ainsi ils confirment des interprétations théoriques anciennes à partir des modèles de flux et de diffusion, et que la distribution de la taille des pores est un moyen important pour optimiser le papier à cigarettes, comme par exemple en ce qui concerne la concentration de monoxyde de carbone dans la fumée d'une cigarette. [Beitr. Tabakforsch. Int 26 (2015) 312-319]

\section{INTRODUCTION}

When a cigarette is smoked normally, it is in one of two different states of flow. During a puff the smoker applies a noticeable pressure difference between the surroundings and the mouth end so that air flows through the cigarette paper into the tobacco rod due to this pressure difference and dilutes the mainstream smoke. This is known as rod ventilation. Therefore air permeability occurs during a pressure-driven flow and is the main property to characterize the cigarette paper during puffing. During smouldering, however, no pressure difference is applied and gases can move around by natural convection or diffuse through the cigarette paper. During this phase, the diffusion capacity characterizes any flow that is driven by concentration differences in this case through the cigarette paper. However, air permeability and diffusion capacity are not completely unrelated. As the flow takes place through the porous structure of the cigarette paper in both cases, it links these two properties.

The relationship between pore size, air permeability and diffusion capacity has in the past been investigated for perforated cigarette papers. For example, in (1) it is concluded that the diffusion coefficient of a gas through perforated paper is virtually the same as that through unperforated paper. Also in (2) the results confirm that the diffusion capacity measured for electrostatically perforated papers was only slightly higher than that of the unperforated base paper. In (2) it is further concluded that the diffusion capacity is governed by small pores in the paper. In (3) the pore size distribution of two cigarette papers is measured by mercury porosimetry and related to the carbon monoxide yields in mainstream smoke.

It seems however, that there are still no systematic studies investigating the effect of cigarette paper composition and paper properties on its pore size distribution. Furthermore the conclusions in (1) and (2) on the influence of small and large pores on air permeability and diffusion capacity mainly compare perforated with naturally porous cigarette papers, are partially based on theoretical considerations only and therefore deserve further experimental verification, in particular for naturally porous cigarette papers. 


\section{MATERIALS AND METHODS}

For these experiments eight naturally porous cigarette papers with similar basis weight were selected, which covered the typical commercial range with respect to filler content, burn additive content and air permeability. All papers were made of wood pulp, except for one, which contained flax pulp. The burn additive was potassium citrate in all cases. The data for all papers is given in Table 1 .

Table 1. Composition and properties of the experimental papers before heating, at $23{ }^{\circ} \mathrm{C}$ and $50 \%$ relative humidity. The nominal burn additive content is given as a percentage of citric acid monohydrate by paper mass.

\begin{tabular}{l|ccccc}
\hline Sample & \multicolumn{5}{c}{ Paper Composition } \\
\hline No. & $\begin{array}{c}\text { Basis } \\
\text { weight } \\
\left(\mathrm{g} / \mathrm{m}^{2}\right)\end{array}$ & $\begin{array}{c}\text { Thickness } \\
(\mathrm{mm})\end{array}$ & Fibres & $\begin{array}{c}\text { Filler } \\
\text { content } \\
\left(\mathrm{g} / \mathrm{m}^{2}\right)\end{array}$ & $\begin{array}{c}\text { Burn } \\
\text { additive } \\
(\%)\end{array}$ \\
1 & 24 & 41 & Wood & 7 & 1.0 \\
2 & 23 & 43 & Flax & 7 & 2.0 \\
3 & 28 & 47 & Wood & 10 & 2.0 \\
4 & 25 & 42 & Wood & 7 & 2.0 \\
5 & 28 & 45 & Wood & 10 & 1.0 \\
6 & 24 & 39 & Wood & 7 & 1.0 \\
7 & 22 & 37 & Wood & 7 & 1.0 \\
8 & 23 & 39 & Wood & 7 & 1.0 \\
\hline
\end{tabular}

Of these papers the air permeability was measured according to ISO 2965, using a Borgwaldt A20 (Borgwaldt KC, Hamburg, Germany) instrument, at first at $23{ }^{\circ} \mathrm{C}$ and $50 \%$ relative humidity $(\mathrm{RH})$, as defined in ISO 187 , and for a second time after the papers had been heated to $230{ }^{\circ} \mathrm{C}$ for $30 \mathrm{~min}$ in a Binder drying oven (Binder $\mathrm{GmbH}$, Tuttlingen, Germany) in the presence of air and then conditioned again according to ISO 187 . The same procedure was repeated for the measurement of diffusion capacity according to CORESTA Recommended Method No. 77. All diffusion capacity measurements were done with a Borgwaldt A50 instrument (Borgwaldt KC, Hamburg, Germany) on a single day with values numerically corrected to $23{ }^{\circ} \mathrm{C}$ and $1013.25 \mathrm{kPa}$. The measurement results for air permeability and diffusion capacity are shown in Table 2.

The pore size distributions of all papers, before and after heating, were measured by mercury porosimetry. Two different instruments were used, a Pascal 140 (Thermo Electron Corp., Milan, Italy), covering a pressure range of $0.01 \mathrm{kPa}$ to $400 \mathrm{kPa}$, which corresponds to a pore radius of $300 \mathrm{~mm}$ to $1.9 \mathrm{~mm}$, and a Pascal 2000 (Thermo Electron Corp., Milan, Italy), covering the pressure range of $0.1 \mathrm{MPa}$ to $200 \mathrm{MPa}$, which allows a measurement of pores with a radius down to $3.7 \mathrm{~nm}$.

At first a glass vial was partially filled with mercury. Then a $1 \mathrm{~cm}$ wide strip of paper weighing about $1 \mathrm{~g}$ was wound up and inserted into the vial. The vial was filled completely with mercury and inserted into the dilatometer. A first measurement was carried out with the Pascal 140 instrument and after completion of the low pressure measurement, the pressure was reduced and the dilatometer was transferred to the Pascal 2000, where the high pressure measurement was carried out.
Table 2. Air permeability (Z) and diffusion capacity $\left(D^{*}\right)$ before and after the paper has been heated to $230^{\circ} \mathrm{C}$ for $30 \mathrm{~min}$ for the experimental papers.

\begin{tabular}{l|c|c|c|c}
\hline \multirow{2}{*}{$\begin{array}{l}\text { Sample } \\
\text { No. }\end{array}$} & \multicolumn{2}{|c|}{$23^{\circ} \mathrm{C}, 50 \% \mathrm{rH}$} & \multicolumn{2}{c}{$\begin{array}{c}\text { Heated to } \\
230^{\circ} \mathrm{C} / 30 \mathrm{~min} .\end{array}$} \\
\cline { 2 - 5 } & $\mathrm{Z}$ & $\mathrm{D}^{*}$ & $\mathrm{Z}$ & $\mathrm{D}^{*}$ \\
$(\mathrm{CU} / \mathrm{s})$ & $(\mathrm{CU})$ & $(\mathrm{cm} / \mathrm{s})$ \\
\hline 1 & 71.3 & 1.50 & 99.4 & 1.98 \\
2 & 68.4 & 2.04 & 108.0 & 2.85 \\
3 & 69.9 & 1.67 & 97.5 & 2.12 \\
4 & 134.1 & 1.74 & 174.5 & 2.28 \\
5 & 50.5 & 1.85 & 59.7 & 2.12 \\
6 & 76.3 & 1.47 & 95.1 & 1.82 \\
7 & 23.5 & 1.18 & 27.6 & 1.42 \\
8 & 47.6 & 1.58 & 62.4 & 2.02 \\
\hline
\end{tabular}

As the measurement ranges of the two instruments overlap, the pore size distributions obtained on the two instruments were stitched together by the analysis software, by matching the overlapping part of the two pore size distributions. Cigarette paper consists of a network of pulp fibres, usually wood or flax pulp fibres, and filler particles, typically chalk, located between the fibres. The pores in cigarette paper hardly resemble the straight or tortuous cylindrical pores used in simple pore models, but rather are an interconnected network of void spaces of widely varying shape. Most of the pores allow a gas flow from one side of the paper to the other, but there are also pores that are open to only one side of the paper and do not provide a pathway to the other side. These dead-end pores contribute to the total pore volume as measured by mercury porosimetry, but do not contribute to air permeability and diffusion capacity as they do not permit a gas flow through the paper.

To reduce the effect of these dead-end pores on the measured pore size distributions, the measurement procedure was repeated twice. In a first run a measurement was carried out using the Pascal 140 and Pascal 2000 instruments as described above. Without opening the dilatometer a second run was performed in the same order, i.e., again first with the Pascal 140 and then with the Pascal 2000. When the pressure is released after the first run, the mercury will be driven out of all pores which pass through the paper but remain in the dead-end pores so that these pores are to a large extent excluded in the results of the second run. Here only the results of this second run are reported.

\section{Qualitative analysis of pore size distributions}

To qualitatively investigate the influence of paper properties and paper composition on the pore size distribution, pairs of cigarette papers were selected from the samples listed in Table 1, which differed only with respect to one parameter. The selected pairs were Samples 7 and 8, which differed only in air permeability with values of $25 \mathrm{CU}$ and $50 \mathrm{CU}$, respectively, then Samples 5 and 8, which differed only in filler content with values of $7 \mathrm{~g} / \mathrm{m}^{2}$ and $10 \mathrm{~g} / \mathrm{m}^{2}$, respectively, and finally Samples 1 and 2, which differed mainly in the type of fibres, containing wood pulp and flax pulp, respectively. Samples 1 and 2 also differed in the burn additive content, but as all these samples were measured without any heat treatment it was assumed that the effect of a $1 \%$ difference in burn additive content on the pore size 
distribution before heat treatment is negligible.

Additionally, the pore size distributions of Sample 1 before and after heat treatment were compared to each other to determine the influence of the heat treatment on cigarette paper.

Correlation between pore size distribution and air permeability or diffusion capacity

The hypothesis to be investigated in this study was that the volume of pores within a certain pore size range is better correlated with air permeability or diffusion capacity than the volume of pores outside this range. In particular the hypothesis was that the volume of small pores is better correlated with diffusion capacity than with air permeability and vice versa the volume of large pores is better correlated with air permeability than with diffusion capacity.

To test this hypothesis the volume of pores within a certain size range needs to be calculated. This can be done by a weighting operation. The pore size distribution V(r), which is the volume of pores $\mathrm{V}$ as a function of the radius $r$, is multiplied by a weighting function $g$. The weighting function depends on the pore radius $r$ and generally has to fulfil the conditions $g(r) \geq 0$ for all $r$ and $\int g(r) d r=1$. Depending on its shape the multiplication of the pore size distribution and the weight function gives more weight to the pore volume within a certain pore size range, while the volume of pores outside this range is suppressed. Apart from the pore radius $r$ the weight function $g$ depends on additional parameters to influence the shape of the weight function and to control which pore size range is given higher weight. Various weight functions for such purposes have become popular and the results usually depend little on the specific weight function, so that in this case a Gaussian weight function $\mathrm{g}(\mathrm{r}, \mu, \sigma)(4)$ was chosen as given in equation [1]. As the pore size distribution is typically determined on a logarithmic scale, that is, $\log (r)$, the logarithm of the pore radius $r$ and the shape parameters $\mu$ and $\sigma$ is used in equation [1], so that on a logarithmic scale the weight function $\mathrm{g}(\mathrm{r}, \mu, \sigma)$ has the typical bell-shape known from the normal distribution.

$$
g(r, \mu, \sigma)=\frac{1}{\log (\sigma) \sqrt{2 \pi}} e-\frac{1}{2}\left(\frac{\log (\mu)-\log (r)}{\log (\sigma)}\right)^{2}
$$

The weight function $\mathrm{g}(\mathrm{r}, \mu, \sigma)$ depends on the pore radius $\mathrm{r}$ and on two shape parameters $\mu$ and $\sigma$, whereby $\mu$ is the position of the maximum of the bell-curve and $\sigma$ controls the width of the weight function, in the same way as mean value and standard deviation determine the shape of a normal distribution. The centre value $\mu$ and the width $\sigma$ will be used for optimization as further explained below. This weight function was multiplied by the pore size distribution $\mathrm{V}(\mathrm{r})$ and integrated to obtain the weighted pore volume $\mathrm{V}_{\mathrm{p}}$ for this pore size distribution, as given in equation [2].

$$
V_{p}(\mu, \sigma)=\int V(r) g(r, \mu, \sigma) d r
$$

Once the weighted pore volume is calculated for each paper sample, the coefficient of correlation between the weighted pore volume and air permeability or diffusion capacity can be determined. This coefficient of correlation, however, still depends on the centre $\mu$ and the width $\sigma$ of the weight function. In an optimization procedure those values for $\mu$ and $\sigma$ were selected which maximized the coefficient of correlation with air permeability $\left(\mu_{\mathrm{Z}}, \sigma_{\mathrm{Z}}\right)$ or diffusion capacity $\left(\mu_{D}, \sigma_{D}\right)$.

In a further analysis a sum of two Gaussian functions [3] with two different centre values $\mu_{1}$ and $\mu_{2}$ but the same width $\sigma$ was chosen as weight function.

$$
g_{\text {alt }}\left(r, \mu_{1}, \mu_{2}, \sigma\right)=g\left(r, \mu_{1}, \sigma\right)+g\left(r, \mu_{2}, \sigma\right)
$$

With this alternative weight function the analysis was repeated, i.e., the three parameters were chosen such that the correlation coefficient between the weighted pore volume and air permeability $\left(\mu_{1, \mathrm{Z}}, \mu_{2, \mathrm{Z}}, \sigma_{12, \mathrm{Z}}\right)$ or diffusion capacity $\left(\mu_{1, \mathrm{D}}, \mu_{2, \mathrm{D}}, \sigma_{12, \mathrm{D}}\right)$, respectively, was maximized.

\section{RESULTS}

The measured air permeability and diffusion capacity, before and after heating, for all papers used in the study is given in Table 2 . The air permeability spans the range from about $20 \mathrm{CU}$ to about $180 \mathrm{CU}$ and therefore covers the range of highest practical relevance. The diffusion capacity varies between $1.18 \mathrm{~cm} / \mathrm{s}$ and $2.85 \mathrm{~cm} / \mathrm{s}$.

\section{Qualitative analysis of pore size distributions}

Figure 1 shows as an example the pore size distribution of paper Sample 1 before heat treatment as measured by mercury porosimetry. All other paper samples had pore size distributions of similar basic shape.

Figure 2 shows the effect of a change in air permeability from $25 \mathrm{CU}$ to $50 \mathrm{CU}$ by comparing the pore size distributions of paper Samples 7 and 8. Figure 3 compares the pore size distributions of the paper Samples 5 and 8, which differ only with respect to the filler content.

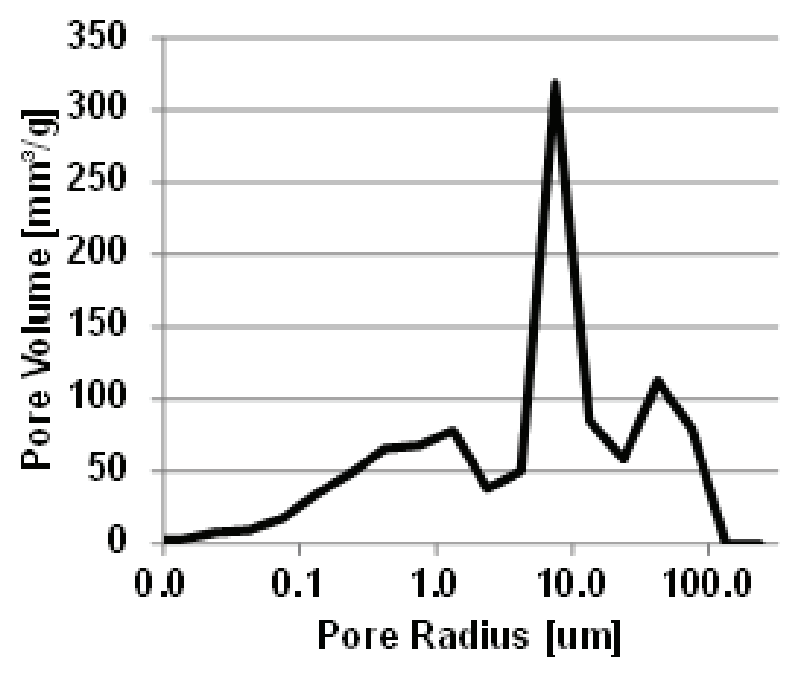

Figure 1. Example pore size distribution of the cigarette papers used in the experiments 


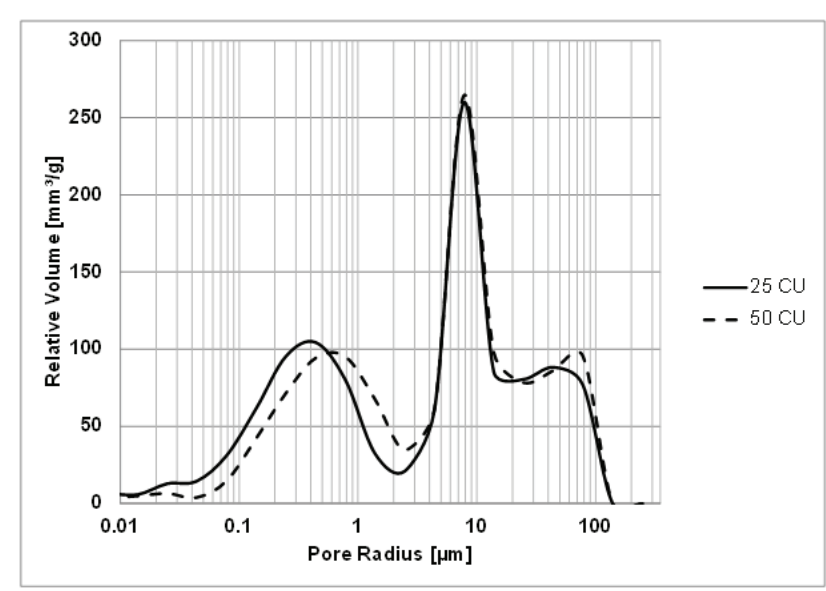

Figure 2. The pore size distributions of two naturally porous paper samples differing only in air permeability (25 CU, $50 \mathrm{CU}$ ).

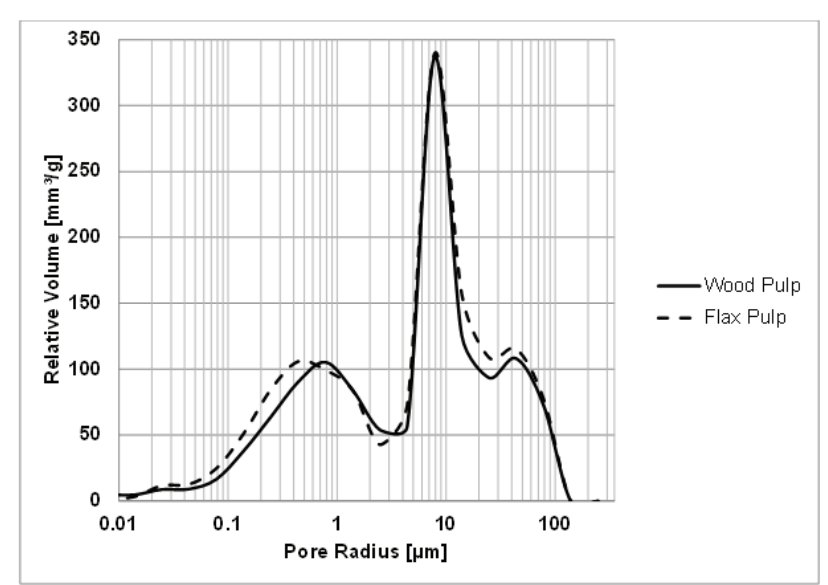

Figure 4. The pore size distributions of two naturally porous paper samples differing in fibre type (wood pulp, flax pulp).

Figure 4 shows the effect of the fibre type on the pore size distribution comparing paper Sample 2, containing flax pulp, with paper Sample 1, containing wood pulp. Figure 5 shows the pore size distribution of paper Sample 1 before and after heat treatment to quantify graphically the effect of the heat treatment.

Correlation between pore size distribution and air permeability or diffusion capacity

Figure 6 shows the coefficient of correlation of the weighted pore volume and air permeability over the parameters $\mu$ and $\sigma$ of the weight function. The optimal parameters for the weight function were $\mu_{\mathrm{Z}}=2.51 \mu \mathrm{m}$ and $\sigma_{\mathrm{Z}}=1.02 \mu \mathrm{m}$.

Figure 7 shows the same results for the correlation with diffusion capacity and the optimal parameter values were $\mu_{\mathrm{D}}=1.00 \mu \mathrm{m}$ and $\sigma_{\mathrm{D}}=2.03 \mu \mathrm{m}$.

Figures 8 and 9 show air permeability and diffusion capacity, respectively, for the paper samples, over the weighted pore volume, calculated for the respective optimal weight function. The correlation coefficient between the weighted pore volume and air permeability was 0.97 , while the correlation coefficient between weighted pore volume and

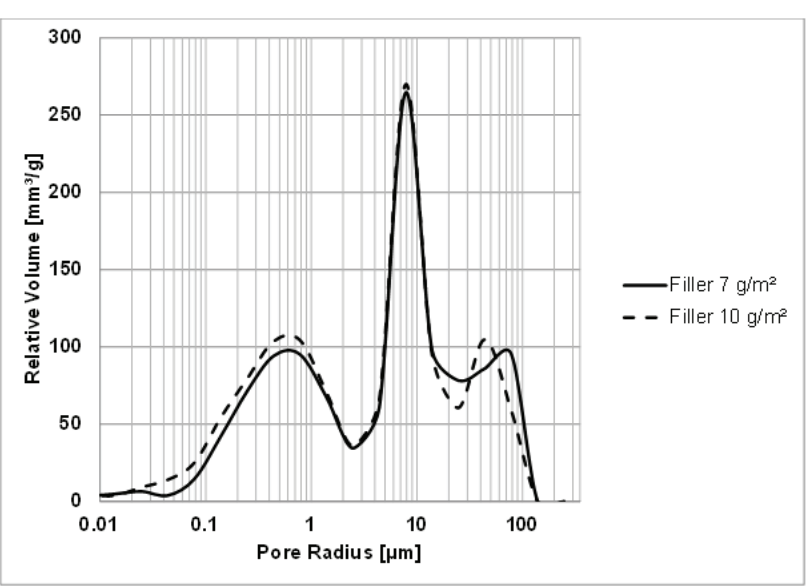

Figure 3. The pore size distributions of two naturally porous paper samples differing only in filler content $\left(7 \mathrm{~g} / \mathrm{m}^{2}, 10 \mathrm{~g} / \mathrm{m}^{2}\right)$.

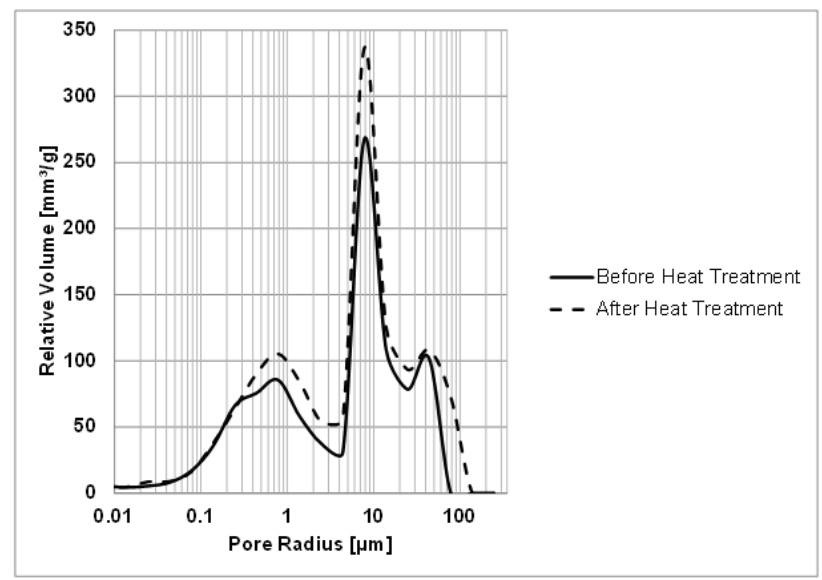

Figure 5. The pore size distributions a naturally porous paper before and after heat treatment $\left(230^{\circ} \mathrm{C}, 30 \mathrm{~min}\right)$.

diffusion capacity was 0.91 . For the correlation between weighted pore volume and diffusion capacity, the values of Sample 2 were excluded as outliers.

Finally, the optimal parameters for the alternative weight function [3] are for air permeability $\mu_{1, Z}=2.51 \mu \mathrm{m}$, $\mu_{2, \mathrm{Z}}=10.0 \mu \mathrm{m}, \sigma_{12, \mathrm{Z}}=1.02 \mu \mathrm{m}$ and for diffusion capacity $\mu_{1, \mathrm{D}}=\mu_{2, \mathrm{D}}=1.0 \mu \mathrm{m}, \sigma_{12, \mathrm{D}}=2.03 \mu \mathrm{m}$. The coefficients of correlation were similar to the results with weight function [1], that is, 0.97 for air permeability and 0.91 for diffusion capacity.

\section{DISCUSSION}

The basic shape of the pore size distribution of a naturally porous cigarette paper is shown in Figure 1. It generally consists of a broad but small peak for a pore radius between $0.1 \mu \mathrm{m}$ and $1.0 \mu \mathrm{m}$ and a narrow but high peak at a pore radius between $5 \mu \mathrm{m}$ and $10 \mu \mathrm{m}$. Pores with a radius of more than $50 \mu \mathrm{m}$ may form a third peak in the pore size distribution. But these pores are large compared to the typical paper thickness of around $30 \mu \mathrm{m}$ to $50 \mu \mathrm{m}$ and cannot be attributed to actual pores in the paper but rather 


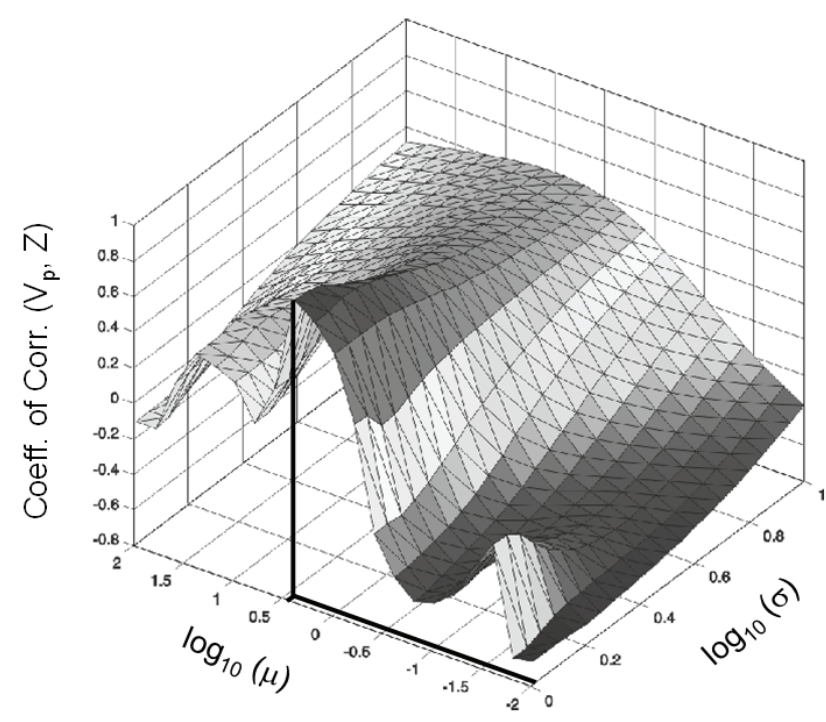

Figure 6. The coefficient of correlation between the weighted pore volume $\left(V_{p}\right)$ and the air permeability $Z$ over the centre $\mu$ and width $\sigma$ of the weight function.

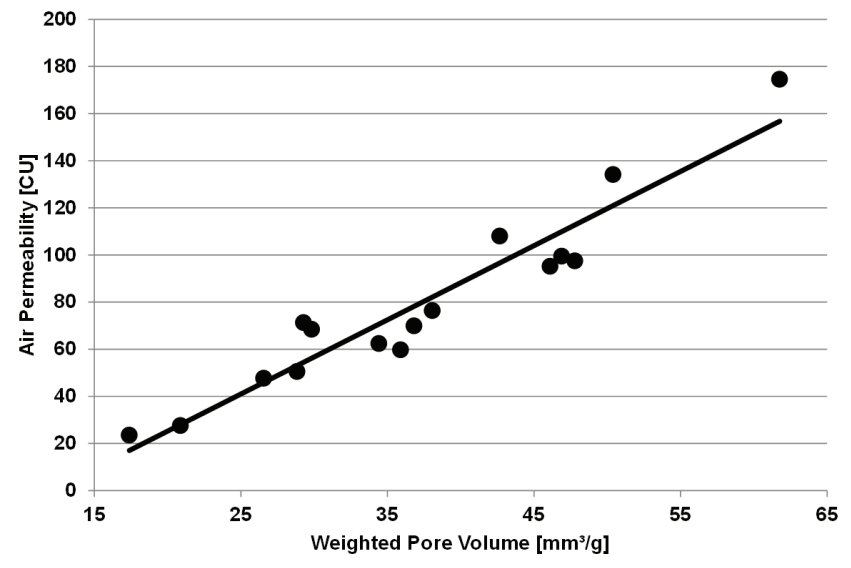

Figure 8. The air permeability over the weighted pore volume, calculated for the optimal weight function. The coefficient of correlation is 0.97 .

to the space between the layers of the tiny paper reel wound up before insertion into the glass vial. This is also confirmed by the fact that compared to the other two peaks the third peak depends on the sample preparation and shows much lower reproducibility. The two-peak shape of the pore size distribution is also in agreement with results shown in (3). Theoretical considerations for simple pore models indicate that for a straight, cylindrical pore of radius $r$, the pressure-driven flow is in good approximation described as a Hagen-Poiseuille flow and is therefore proportional to $\mathrm{r}^{4}$. In other words, air permeability $\mathrm{Z}$ is proportional to $\mathrm{r}^{4}$.

In contrast the diffusive flow through the same pore is by Fick's law only proportional to $r^{2}$, which means that diffusion capacity $\mathrm{D}^{*}$ is proportional to $\mathrm{r}^{2}$. As a consequence a pore with a comparably large diameter will contribute much more to air permeability than to diffusion capacity. This conclusion may be valid for the straight pores of perforation holes, but for the pores in naturally porous cigarette paper it is quite likely that, together with the pore diameter, the pore

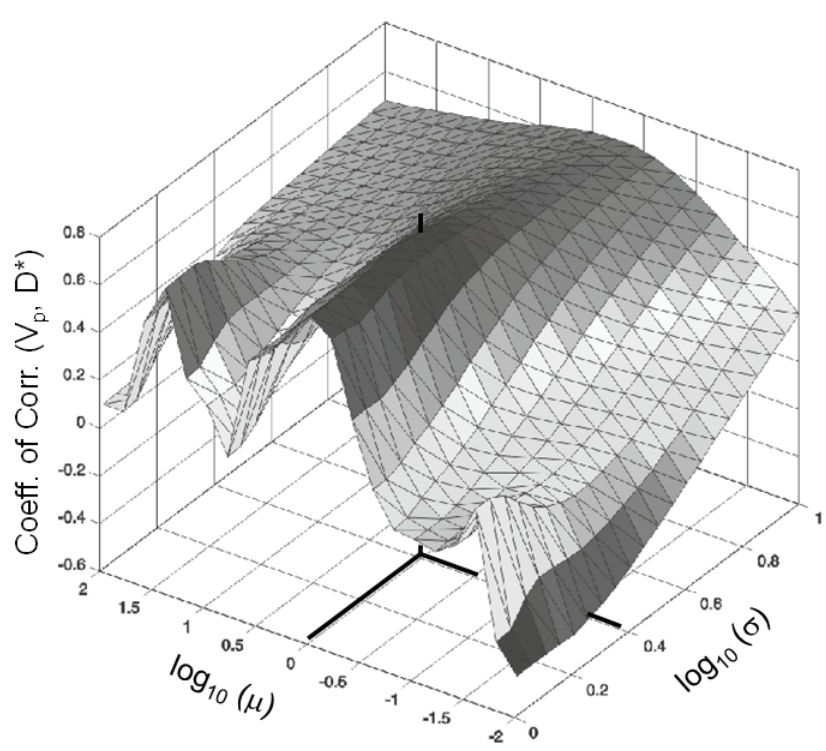

Figure 7. The coefficient of correlation between the weighted pore volume $\left(V_{p}\right)$ and diffusion capacity $D^{*}$ over the centre $\mu$ and width $\sigma$ of the weight function.

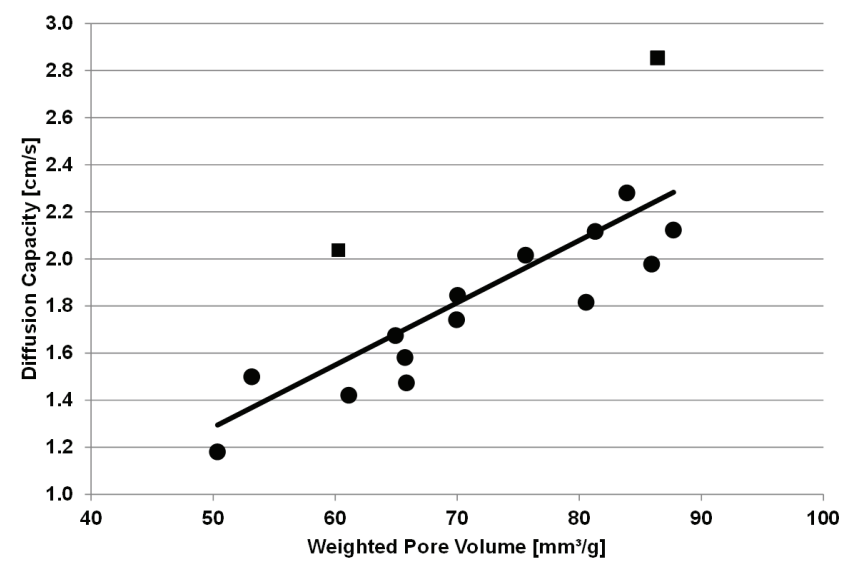

Figure 9. The diffusion capacity over the weighted pore volume, calculated for the optimal weight function. The coefficient of correlation is $\mathbf{0 . 9 1}$. The values for the paper containing flax pulp (small squares) had to be excluded as outliers.

length will change substantially and may invalidate the assumption of a straight cylindrical pore, that is, the tortuosity of the pores is likely to be a significant influencing factor. Nevertheless previous experimental data (1) and theoretical considerations $(1,5)$ have shown that there is an approximate proportionality between $\sqrt{Z}$ and $\mathrm{D}^{*}$, which to some extent supports this simple pore model. This proportionality holds particularly well, if the air permeability is only adjusted by the refining of the pulp fibres.

\section{Qualitative analysis of pore size distributions}

Figure 2 compares paper Samples 7 and 8 with an air permeability of $25 \mathrm{CU}$ and $50 \mathrm{CU}$, respectively. As can be seen the broad peak between $0.1 \mu \mathrm{m}$ and $1.0 \mu \mathrm{m}$ shifts slightly to higher pore radii, while the total pore volume in this pore size range appears to remain approximately unchanged. For the peak between $5 \mu \mathrm{m}$ and $10 \mu \mathrm{m}$ the 
results indicate a slight increase in pore volume, while the position of the peak maximum is unchanged. The proportionality factors $\sqrt{Z} / D^{*}$ for Sample 7 of $\sqrt{23.5} / 1.18=0.243$ and for Sample 8 of $\sqrt{47.6} / 1.58=0.229$ are very similar, which agrees with expectations as the air permeability was only adjusted by refining of the pulp fibres.

Figure 3 shows the pore size distributions of Samples 5 and 8 , which differ in the filler content. The peak between $0.1 \mu \mathrm{m}$ and $1.0 \mu \mathrm{m}$ pore radius is unchanged in its position but there is a slight overall increase in pore volume in this pore size range. In contrast the peak between $5 \mu \mathrm{m}$ and $10 \mu \mathrm{m}$ is unchanged in volume and position. This specific increase in the volume of small pores causes an increase in diffusion capacity, here from $1.58 \mathrm{~cm} / \mathrm{s}$ to $1.84 \mathrm{~cm} / \mathrm{s}$, while the air permeability is practically unchanged. Consequently, also the proportionality factors $\sqrt{Z} / \mathrm{D}^{*}$ for Sample 8 of 0.229 as above and for Sample 5 of $\sqrt{50.5} / 1.84=0.259$ differ more than when the air permeability is adjusted by refining. Thus the filler is one of the few paper components which allows an adjustment of diffusion capacity while keeping the air permeability constant.

It has to be noted that Samples 5 and 8 also differed in thickness, which is due to the increase in basis weight by adding $3 \mathrm{~g} / \mathrm{m}^{2}$ of filler. But as Sample 5 has higher filler content, higher thickness $(45 \mu \mathrm{m})$ and higher diffusion capacity than Sample 8, it may be assumed for papers of the same thickness but differing filler content that the effect on the diffusion capacity is even stronger as the diffusion pathways will be shorter.

Figure 4 compares two cigarette papers, Sample 1, made of wood pulp, and Sample 2, made of flax pulp. As can be seen a switch from wood pulp to flax pulp causes the peak between $0.1 \mu \mathrm{m}$ and $1.0 \mu \mathrm{m}$ pore radius in the pore size distribution to shift towards lower pore radii, while the large peak between $5 \mu \mathrm{m}$ and $10 \mu \mathrm{m}$ does not change. The overall pore volume is approximately unchanged. In the simple pore model mentioned above, that is at constant pore length, a reduction of the pore radius at constant pore volume means an increase in the number of pores, which increases diffusion capacity. This is confirmed in the experiments which show an increase from $1.50 \mathrm{~cm} / \mathrm{s}$ for the wood pulp paper to $2.04 \mathrm{~cm} / \mathrm{s}$ for the flax pulp paper, both values at $23{ }^{\circ} \mathrm{C}$ and $50 \% \mathrm{RH}$. Also the proportionality factors $\sqrt{Z} / \mathrm{D}^{*}$ differ substantially with $\sqrt{71.3} / 1.50=0.178$ for the wood pulp paper and $\sqrt{68.4} / 2.04=0.247$ for the flax pulp paper. Therefore also a switch from wood pulp to flax pulp can be used as a tool to increase diffusion capacity at constant air permeability, but compared to an increase in filler content such a change on a cigarette may have an impact on the cigarette taste.

Finally Figure 5 shows the pore size distributions of paper Sample 1 before and after heat treatment. At $230{ }^{\circ} \mathrm{C}$ the cellulose in the paper has already started to decompose and the paper will acquire a light to dark brown colour, but it is still stable enough for measurements. The pore size distributions show an overall increase in the pore volume for pore sizes above about $0.3 \mu \mathrm{m}$ radius, which leads to a substantial increase in air permeability and diffusion capacity. The proportionality factor $\sqrt{Z} / \mathrm{D}^{*}$ is 0.178 , as above, before heating and $\sqrt{99.4} / 1.98=0.199$ after heat treatment. It changes slightly but less than when the fibre type or the filler content is changed. Understanding the pore size distribution of heat treated cigarette paper is important, because a substantial part of the flow on a cigarette takes place in the region of the glowing cone, where the cigarette paper is already partially thermally decomposed.

As a summary the qualitative analysis of the pore size distributions shows that filler content and fibre type can be tools to adjust diffusion capacity and air permeability independently at least to some extent, but the relationship between these two properties via the pore size distribution still remains strong.

\section{Correlation between pore size distribution and air permeability or diffusion capacity}

The purpose of the weight functions [1] or [3] introduced above is to cut out a certain pore size range from the pore size distribution to check if the pore volume in this pore size range is correlated with either air permeability or diffusion capacity. The optimal centre and width of the weighting function thus indicate which pore size range is correlated with air permeability or diffusion capacity.

The centre values for the maximum coefficient of correlation for air permeability, Figure 6, and for diffusion capacity, Figure 7, appear to be rather robust, as a change in the width of the weight function does not have a significant influence on the optimal centre values $\mu_{\mathrm{Z}}$ or $\mu_{\mathrm{D}}$. For the optimal weight function a coefficient of correlation of 0.97 could be achieved between the weighted pore volume and air permeability. The coefficient of correlation between weighted pore volume and diffusion capacity is slightly lower, but with 0.91 still at an acceptable level, especially when considering that in the analysis no difference was made between papers before and after heat treatment.

From Figures 8 and 9, which show air permeability and diffusion capacity, respectively, over the weighted pore volume, calculated for the optimal weight function, it has to be noted that the regression line does not pass through the origin in both cases. This means that the correlation is just between changes in the weighted pore volume and changes in air permeability or diffusion capacity.

Furthermore Sample 2 was excluded as an outlier in the correlation between weighted pore volume and diffusion capacity. As Sample 2 was the only flax paper in this study, it remains an open question, whether the values were actual outliers or if the porous structure of a flax paper differs from that of wood pulp papers to such an extent that the correlation model used here cannot be applied to flax and wood pulp papers together.

An optimal centre value for air permeability of $\mu_{\mathrm{z}}=2.51 \mu \mathrm{m}$ means that a change in air permeability is positively correlated with a change in the volume of pores with a radius of about $2.51 \mu \mathrm{m}$.

For diffusion capacity the optimal centre value, $\mu_{\mathrm{D}}=1.0 \mu \mathrm{m}$, is smaller than for air permeability, which supports the conclusion that pores of larger diameter are better correlated with air permeability, while pores with smaller diameter are better correlated with diffusion capacity, as predicted by the simple pore model. Looking at the typical pore size distribution of a naturally porous cigarette paper, however, it appears surprising that the large peak between $5 \mu \mathrm{m}$ and $10 \mu \mathrm{m}$, which constitutes approximately $45 \%$ to $55 \%$ of the entire pore volume, did not seem to be well correlated with air permeability or diffusion capacity. 
To check this, the alternative weight function [3] was used, which comprises two maxima and thereby can cut out two different pore size ranges for correlation with air permeability or diffusion capacity. The results with this alternative weight function indicate that the large peak between $5 \mu \mathrm{m}$ and $10 \mu \mathrm{m}$ also contributes to the correlation between the weighted pore volume and air permeability, which further supports the conclusion that large pores govern air permeability. In contrast the same analysis for diffusion capacity shows that the peak between $5 \mu \mathrm{m}$ and $10 \mu \mathrm{m}$ remains irrelevant and the two maxima of the alternative weight function [3] exactly overlap at $1.0 \mu \mathrm{m}$.

\section{CONCLUSIONS}

The pore size distributions of eight naturally porous cigarette papers were measured by mercury porosimetry and the measured distributions were investigated from two different perspectives. In a first qualitative analysis the influence of air permeability, filler content, fibre type and a heat treatment on the pore size distribution of the cigarette paper was determined. The results are in agreement with qualitative predictions from simple pore models and show that filler content and fibre type can be tools to adjust the diffusion capacity while keeping the air permeability constant.

In a second approach a correlation between a weighted pore volume and air permeability or diffusion capacity was established. The results indicate that changes in air permeability are well correlated with changes in the volume of pores with a radius between $2.5 \mu \mathrm{m}$ and $10 \mu \mathrm{m}$, while changes in the volume of pores with about $1.0 \mu \mathrm{m}$ radius are correlated with changes in diffusion capacity. These results support the general conclusion that diffusion capacity is governed by small pores while the air permeability is governed by large pores.

Together with past research this study confirms that air permeability and diffusion capacity are in fact two different parameters of the cigarette paper having an independent physical meaning and independent importance for controlling the smoke yields and in particular carbon monoxide yields of a cigarette. However, the results also show that air permeability and diffusion capacity are both tightly linked to the porous structure of the cigarette paper, which substantially limits the options in cigarette paper design to adjust air permeability and diffusion capacity independently.

As cigarette filters usually do not effectively remove carbon monoxide or some other gas phase components from the smoke, filter ventilation and the cigarette paper are the main tools to reduce the carbon monoxide content in mainstream smoke. If, for example, filter ventilation is not available as a design tool, out of special cigarette design considerations or because of regulatory requirements, the filter can be modified to remove more particulate matter ('tar') but the content of carbon monoxide and other gas phase components in cigarette smoke will increase. Due to the tight link between air permeability and diffusion capacity this increase in carbon monoxide yields cannot be compensated by simply increasing the diffusion capacity of the cigarette paper only. An increase of the diffusion capacity will significantly affect other parameters of the cigarette paper and in consequence also the entire cigarette design.

\section{REFERENCES}

1. Baker, R.R. and R.A. Crellin: The Diffusion of Carbon Monoxide out of Cigarettes; Beitr. Tabakforsch. 9 (1977) 131-140.

2. Norman A.B., J.C. Caudle, and C.W. Henderson: Measurement of Gas Diffusion Capacity of Cigarette Papers; Beitr. Tabakforsch. Int. 21 (2005) 425-434.

3. Yin D., W. Luo., D. Ding, Z. Chen, K. Zhong., and J. Ren: Effect of Pore Structure Characteristics of Cigarette Paper on Carbon Monoxide Release in Mainstream Smoke During Cigarette Burning Process; Abstract ST23, CORESTA Congress 2015, Québec, Canada.

4. Fahrmeir L., R. Künstler, I. Pigeot, and G. Tutz: Statistik - Der Weg zur Datenanalyse; 5th Edition, Springer Verlag, 2004, pp 100-101.

5. Eitzinger B. and C. Mair: The Influence of the Pore Size Distribution of Cigarette Paper on Its Diffusion Constant and Air Permeability, Abstract SSPT17, CORESTA SSPT Meeting 2005, Stratford-upon-Avon, UK.

Corresponding author:

Bernhard Eitzinger

delfortgroup $A G$

Fabrikstr. 20

4050 Traun

Austria

E-mail: Bernhard.Eitzinger@delfortgroup.com 